Pete Hoskins, short stop; Sam Sager, Sturgis Anson and Milton Ellis in the outfield, with A. J. Cooper, substitute. The game was played in Des Moines, and the victory won by Marshalltown.

The narrative deals extensively with Anson's life with the Chicago league team and its trip around the world, playing with local teams at numerous stopping places and indoctrinating individual players in foreign countries with the intricacies of clever fielding and place hitting. It is illustrated profusely, the frontispiece being a half-tone engraving of the author in his Chicago Uniform. An excellent likeness of Hon. Henry Anson, his father, and the first mayor of Marshalltown, is shown, as also are pictures of Mr. Anson's family and their children, and "Billy". Sunday, with various scenes at places visited by the Chicago club upon its pilgrimages.

A prized exhibit in the Chicago Historical Society's new display is the base ball bat used by Cap. Anson back in 1883 to set an all-times homer record, when he hit five homers in five consecutive times at bat. The display characterized "The National Game" and dramatizes 90 years of professional baseball.

\title{
Local Community Weathervanes
}

There were those who, without attaining eminence, were the most prominent citizens in the communities in which they. lived and were chiefly instrumental in giving character and direction to. social and political affairs. Though people unversed in politics seldom realize it, in a representative government these local leaders of public opinion play roles as indispensable as the more distinguished elective and appointive officers. In fact, without the support and encouragement of these local leaders of public opinion high elective officials would be in the position of a general attempting to lead an army into battle without line officers. -Arthur T. Vanderbilt in the South Atlantic Quarterly. 
Copyright of Annals of Iowa is the property of State of Iowa, by \& through the State Historical Society of Iowa and its content may not be copied or emailed to multiple sites or posted to a listserv without the copyright holder's express written permission. However, users may print, download, or email articles for individual use. 